\title{
Surface irrigation with saline water on a heavy clay soil in the Medjerda Valley, Tunisia
}

\author{
J. A. van 't Leven and M. A. Haddad
}

Institute for Land and Water Management Research (I.C.W.), P.O. Box 35, Wageningen, The Netherlands;

Office de la Mise en Valeur de la Basse Vallée de la Medjerda, Tunis, Tunisia

Received 29 March, 1967

\section{Summary}

At an early moment it was clear that the soil texture and the salinity of the irrigation water used in the Medjerda Valley would lead to a salinization problem. The Tunisian Government therefore decided to set up an experiment in the valley, where the relationships of climatological factors, irrigation with saline water, drainage, salinity of the soil, crop growth and crop rotation could be studied.

The present article gives, after mentioning some features of the Merjerda Project, the results of and the conclusions to be drawn from the experiments on salinity during the years 1962 through 1964.

\section{The Medjerda Project}

\section{General}

The Medjerda River flows from west to east in the northern part of Tunisia (Fig. 1). It rises in Algeria and runs into the Gulf of Tunis in the Mediterranean. The river is fed by many tributaries, of which Oued Mellegue, Oued Tessa, Oued Silliana and Oued Kesseb are the most important. In the upstream part the meandering river has cut a deep valley through the hills and mountains. At a distance of about $40 \mathrm{~km}$ westwards of the town of Tunis it enters a wide plain, which was in ancient times a part of the Gulf of Tunis. In the course of centuries the river carried so much sediment that a part of the gulf has been filled up to the present western boundary of the gulf.

A part of these low lands of fine-textured soils is topografically sufficiently high that the cultivation of some agricultural crops is possible. Other parts are too low and can be characterized as marshy areas with a high water table, especially in winter. From time to time the Medjerda River, being an intermittent stream, discharges large quantities of water, partly due to the rapid run-off of rain from the surrounding barren mountain slopes. In the valley, this meandering river on flat gradient frequently overflows its banks and floods extensive areas.

For the Tunisian government the reclamation of this vast lowland plain of 220,000 ha ( 1 ha $=2.47$ acres) is of great importance because the present area under cultivation is not rich in good soils and newly reclaimed new lands may help to increase the food production for a rapid growing population (see also Westerhof, 1962). 


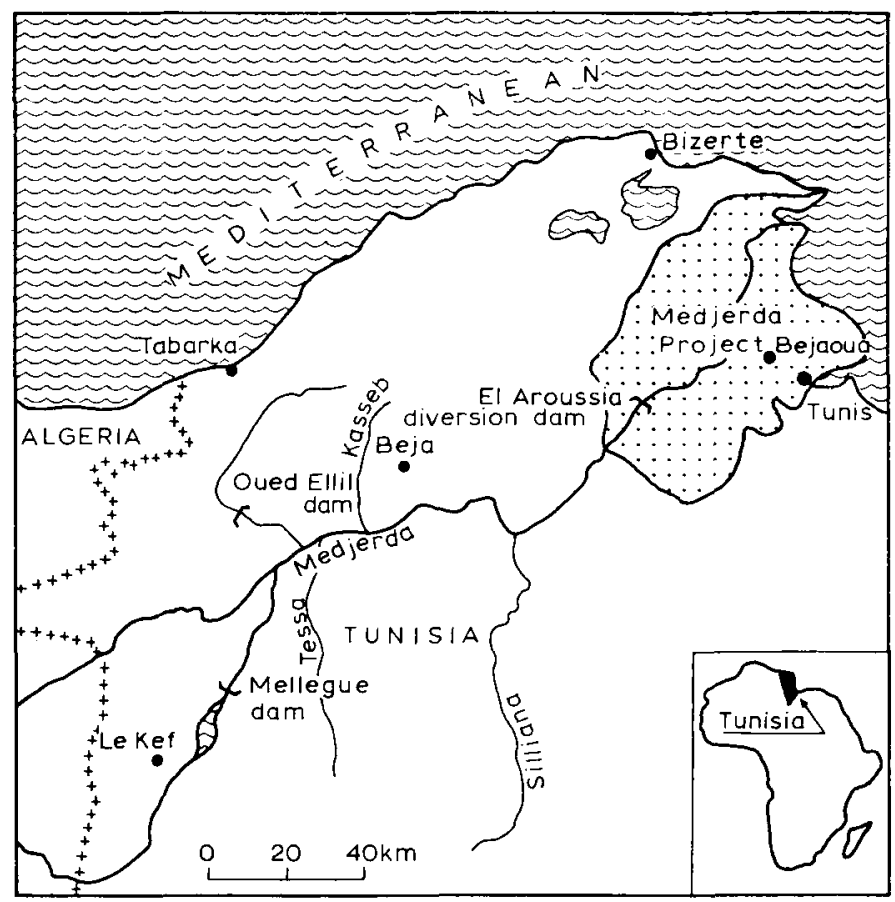

Fig. 1 Situation map of the Medjerda Project.

The Office de la Mise en Valeur de la Basse Vallée de la Medjerda (O.M.V.V.M.) in Tunis was charged with the execution of this immense task. In order to carry it out the O.M.V.V.M. invited a number of experts.

In this connection the Institute for Land and Water Management Research at Wageningen, The Netherlands, contributed by sending experts on soil salinity and drainage (see van Hoorn, 1963; van 't Leven, 1964). In this paper the investigation procedure is described and some of the results and conclusions are discussed with the exception of the work done on evapotranspiration that will be published at a later date.

\section{Soil characteristics}

As was mentioned, the soils in the plain have been deposited by the Medjerda River. In general they can be characterized as heavy clay soils (more than $35 \%<2 \mu$ ). They have a high lime content $(35 \%)$. The groundwater at shallow depth is saline. Before the execution of the project the groundwater table after a rainy period in winter time was at the soil surface or just below, even in the cultivated areas.

The permeability of the greater part of these soils is relatively low $(0.1-0.5 \mathrm{~m} /$ day $)$ if the soil is in wet condition, as in the months of February and March, during and soon after the rainy season. At this time the infiltration rate is also relatively low, in part as a consequence of the rain deteriorating the structure of the upper soil layer. During the growing season, on the contrary, with high evapotranspiration rates the soil shrinks and cracks (fissures up to $5 \mathrm{~cm}$ wide), increasing permeability considerably. 
Table I Monthly precipitation at Bejaoua during 1962 and 1963, mean precipitation at Tunis-Manoubia (1901-1959) and the evapotranspiration

\begin{tabular}{|c|c|c|c|c|c|c|}
\hline & \multicolumn{3}{|c|}{$\begin{array}{l}\text { Precipitation } \\
\quad(\mathrm{mm})\end{array}$} & \multicolumn{2}{|c|}{$\begin{array}{l}\text { Potential evapo- } \\
\text { transpiration alfalfa }\end{array}$} & \multirow{2}{*}{$\begin{array}{c}E_{0} \text { acc. } \\
\text { Penman } \\
1901-1959\end{array}$} \\
\hline & 1962 & 1963 & $1901-1959$ & 1962 & 1963 & \\
\hline Jan. & 49.9 & 59.9 & 66 & - & 53 & 44 \\
\hline Febr. & 71.4 & 81.6 & 50 & - & 31 & 62 \\
\hline March & 48.0 & 43.2 & 42 & 102 & 112 & 101 \\
\hline April & 48.2 & 48.4 & 39 & 105 & 123 & 132 \\
\hline May & 11.3 & 18.3 & 22 & 229 & 214 & 180 \\
\hline June & 10.3 & 48.9 & 10 & 288 & 231 & 222 \\
\hline July & 0.0 & 20.0 & 2 & 366 & 310 & 248 \\
\hline August & 0.0 & 4.2 & 7 & 248 & 310 & 220 \\
\hline Sept. & 30.1 & 66.9 & 34 & 165 & 195 & 156 \\
\hline Oct. & 122.1 & 39.3 & 56 & 136 & 127 & 102 \\
\hline Nov. & 23.5 & 10.2 & 56 & 54 & 162 & 63 \\
\hline Dec. & 21.4 & 84.2 & 63 & 53 & 68 & 44 \\
\hline Total & 436.2 & 519.1 & 447 & & 1936 & 1574 \\
\hline
\end{tabular}

\section{Climate}

In Table 1 the precipitation during 1962 and 1963 is given for the meteorological station of Bejaoua. To compare these data with the mean precipitation for that region, the mean values for a 58 years period from 1901-1959 are indicated for the TunisManoubia station of the National Meteorological Service (van Hoorn, 1961). In the last columns the potential evapotranspiration (PET) of the alfalfa is given and the $\mathrm{E}_{\mathrm{o}}$ according to the formula of Penman.

The precipitation in 1962 is less than the mean for the 58 years period but that of 1963 is considerably more. The months of June, July and August are very dry.

December and January are generally the months with the highest precipitation. Only the precipitation in January and February has a leaching effect, because the larger part of rainwater in December is still needed for moistening the soil profile. During 8-9 months of the year the subsequent crops need irrigation.

A number of times very high intensities of rainfall have been measured, as for example in November 1962. One shower had an intensity of $37 \mathrm{~mm}$ in 34 minutes. The greater part of the water of these heavy showers runs off immediately into the drainage canals and does not infiltrate into the soil. From the point of view of soil moistening or desalinization this water is lost.

The minimum temperature in the months of January, February and March is low. Particularly in February and the beginning of March night frost occurs, which sometimes causes severe damage to the crops. In summer during the so-called 'Sirocco' the temperature rises up to $45^{\circ} \mathrm{C}$.

\section{The dams}

To date reservoir dams have been built in the Oued Ellil and Oued Mellegue and a diversion dam in the Oued Medjerda. The Oued Ellil is a small stream having its source in the cork-oak forests of the mountains in North Tunisia. The quality of the water in the reservoir near the village of Ben Metir was sufficiently good $(200 \mathrm{mg}$ total salt per litre) to use it as drinking water for the town of Tunis and its environ- 
ments. The catchment basin, covering an area of $108 \mathrm{~km}^{2}$, has a mean annual rainfall of $1200 \mathrm{~mm}$. Any surplus is used for irrigation purposes.

The Oued Mellegue is the main tributary of the river Medjerda. The catchment basin covering an area of $10,000 \mathrm{~km}^{2}$ has a mean annual rainfall of $400 \mathrm{~mm}$. The capacity of the storage reservoir, near the village of Nebeur, is considerably higher than of the one mentioned above. However, the quality of the water is notably lower, the salt content is more than 2000 p.p.m.

This water is used for irrigation of the lowlands of the Medjerda.

The Oued Medjerda has a diversion dam near El Aroussia for the irrigation distribution system. The dam is built $10 \mathrm{~km}$ upstream from Tebourba, where the river enters the plain. The minimum discharge of the river is $15 \mathrm{~m}^{3} / \mathrm{sec}$, of which $1 \mathrm{~m}^{3} / \mathrm{sec}$ passes the dam to supply irrigation water to the fields adjacent to the river.

It is estimated that in total $250 \times 10^{6} \mathrm{~m}^{3}$ per year is available for irrigation purposes. Besides this quantity, $650 \times 10^{6} \mathrm{~m}^{3}$ per year are still flowing into the sea.

\section{The irrigation and drainage system}

Water is distributed from the main irrigation canal to laterals and flows by gravity, or is pumped, to the irrigated parcels. The irrigation system is of the French Neyrpic type.

From the concrete irrigation flumes the water flows in 'seguias' or earthen canals. Via the seguias the water is fed into basins.

A relatively deep and narrow spaced drainage system was required because of the heavy clay soils, brackish irrigation water supply, saline groundwater and a high water table.

The average drain depth was fixed at at least $150 \mathrm{~cm}$. This depth still allows discharge by gravity. Experiences elsewhere (e.g. Talsma, 1963) have indicated that this depth will reduce capillary rise in the rootzone sufficiently. The salt content of the soil will therefore be influenced favourably.

The permeability of the soil of the whole area to be irrigated was calculated with the augerhole method of Hooghoudt (van Beers, 1958). In a number of cases it was impossible to determine it because the groundwater table was too deep.

In general a drain radius of $10 \mathrm{~cm}$ and a drain spacing of 40 to $60 \mathrm{~m}$ was recommended. The latter was calculated with Hooghoudt's formula (Hooghoudt, 1934) :

$\mathbf{s}=\frac{8 \mathrm{k}_{\mathrm{o}} \mathrm{dm} \mathrm{m}_{\mathrm{o}}+4 \mathrm{k}_{\mathrm{b}} \mathrm{m}_{\mathrm{o}}^{2}}{\mathrm{~L}^{2}}$

where :

$\mathrm{s}=$ discharge per $24 \mathrm{~h}$, expressed as a surface layer of water in metres,

$\mathrm{k}_{\mathrm{o}}=$ hydraulic conductivity in $\mathrm{m} / 24 \mathrm{~h}$ of the soil below the level of the drains,

$\mathrm{k}_{\mathrm{b}}=$ the same of the soil above the level of the drains (in our case $\mathrm{k}_{o}$ equalled $\mathrm{k}_{\mathrm{b}}$ ),

$\mathrm{m}_{\mathrm{o}}=$ hydraulic head midway between the drains, in metres,

$\mathrm{d}=$ depth of equivalent layer in metres, a function of the radius of the drains $\mathrm{r}_{\mathrm{o}}$, of the distance $\mathbf{H}$ that the impermeable layer lies below the drains, and of the drain spacing,

$\mathrm{L}=$ drain spacing in metres.

The tile lines discharge into open drains. The saline drain water flows to the river and then to the sea. Often along the banks of the Medjerda river farmers have to use this more saline mixture of river- and drainage water. 
The salinity of the water in the Medjerda River at the dam of El Aroussia

To determine the degree of salinity, water samples are taken at several places in the river and in the irrigation canals. Near the dam of El Aroussia, where the irrigation water is diverted, samples are taken every day.

Fig. 2 shows the daily fluctuations in the electric conductivity (EC) for the period 1960 to and including 1963 in mmho's at $25^{\circ} \mathrm{C}$. The monthly means of 1962 and 1963 are given in Table 2, converted from EC to grams per litre.

It should be noted that the EC of the irrigation water when it arrives at the farm is somewhat higher than at the dam due to evaporation during the transport.

During the greater part of the year the irrigation water can be used only if such precautionary measures as drainage, leaching and a good choice of medium salt tolerant crops are taken.

Table 3 shows some chemical analyses of the irrigation water from the series of

Table 2 Salt content of the water from the Medjerda River at $E l$ Aroussia before it enters the irrigation area; monthly mean in grams per litre

\begin{tabular}{lrr} 
& & \\
& 1962 & 1963 \\
January & 2.434 & 1.442 \\
February & 0.847 & 0.828 \\
March & 1.391 & 1.351 \\
April & 1.627 & 1.427 \\
May & 2.105 & 1.736 \\
June & 2.735 & 2.121 \\
July & 3.098 & 2.781 \\
August & 2.804 & 2.336 \\
September & 2.716 & 1.815 \\
October & 1.958 & 2.191 \\
November & 1.570 & 2.574 \\
December & 1.699 & 1.762 \\
& & \\
\hline
\end{tabular}

Table 3 Chemical analyses of the irrigation water from the Medjerda at El Aroussia

\begin{tabular}{|c|c|c|c|c|c|c|c|c|c|}
\hline \multirow[t]{2}{*}{ Date } & \multicolumn{6}{|c|}{ Components in $\mathrm{mg} / \mathrm{l}$} & \multirow{2}{*}{$\begin{array}{c}E C \\
a t \\
25^{\circ} \mathrm{C} \\
\left(\times 10^{3}\right)\end{array}$} & \multirow{2}{*}{$\begin{array}{c}\text { Calcul. } \\
\text { salt } \\
\text { content in } \\
m g / l \\
(K=0.66)\end{array}$} & \multirow[t]{2}{*}{$S A R$} \\
\hline & $\mathrm{Cl}$ & $\mathrm{SO}_{4}$ & $\mathrm{CO}_{3}$ & $\mathrm{Ca}$ & $M g$ & $\mathrm{Na}$ & & & \\
\hline $\begin{array}{l}13-8-61 \\
26-8-61\end{array}$ & $\begin{array}{r}944 \\
1194\end{array}$ & $\begin{array}{r}898 \\
1046\end{array}$ & $\begin{array}{l}63 \\
66\end{array}$ & $\begin{array}{l}224 \\
256\end{array}$ & $\begin{array}{r}92 \\
107\end{array}$ & $\begin{array}{l}660 \\
780\end{array}$ & $\begin{array}{l}1.55 \\
5.30\end{array}$ & $\begin{array}{l}3160 \\
3640\end{array}$ & $\begin{array}{r}9.3 \\
10.3\end{array}$ \\
\hline $\begin{array}{l}12-4-62 \\
24-4-62\end{array}$ & $\begin{array}{l}675 \\
320\end{array}$ & $\begin{array}{l}461 \\
288\end{array}$ & $\begin{array}{l}96 \\
78\end{array}$ & $\begin{array}{r}152 \\
76\end{array}$ & $\begin{array}{l}73 \\
46\end{array}$ & $\begin{array}{l}400 \\
200\end{array}$ & $\begin{array}{l}3.00 \\
1.70\end{array}$ & $\begin{array}{l}2000 \\
1060\end{array}$ & $\begin{array}{l}6.6 \\
4.1\end{array}$ \\
\hline $\begin{array}{l}18-4-63 \\
23-4-63\end{array}$ & $\begin{array}{l}568 \\
142\end{array}$ & $\begin{array}{l}396 \\
148\end{array}$ & $\begin{array}{l}102 \\
102\end{array}$ & $\begin{array}{r}152 \\
72\end{array}$ & $\begin{array}{l}68 \\
24\end{array}$ & $\begin{array}{r}360 \\
80\end{array}$ & $\begin{array}{l}2.75 \\
0.90\end{array}$ & $\begin{array}{r}1820 \\
590\end{array}$ & $\begin{array}{l}6.0 \\
2.0\end{array}$ \\
\hline $\begin{array}{r}7-8-63 \\
31-8-63\end{array}$ & $\begin{array}{l}568 \\
994\end{array}$ & $\begin{array}{l}643 \\
956\end{array}$ & $\begin{array}{l}84 \\
84\end{array}$ & $\begin{array}{l}152 \\
200\end{array}$ & $\begin{array}{r}68 \\
107\end{array}$ & $\begin{array}{l}420 \\
700\end{array}$ & $\begin{array}{l}2.95 \\
4.70\end{array}$ & $\begin{array}{l}1950 \\
4100\end{array}$ & $\begin{array}{r}7.0 \\
10.0\end{array}$ \\
\hline
\end{tabular}


J. A. VAN 'T LEVEN AND M. A. HADDAD

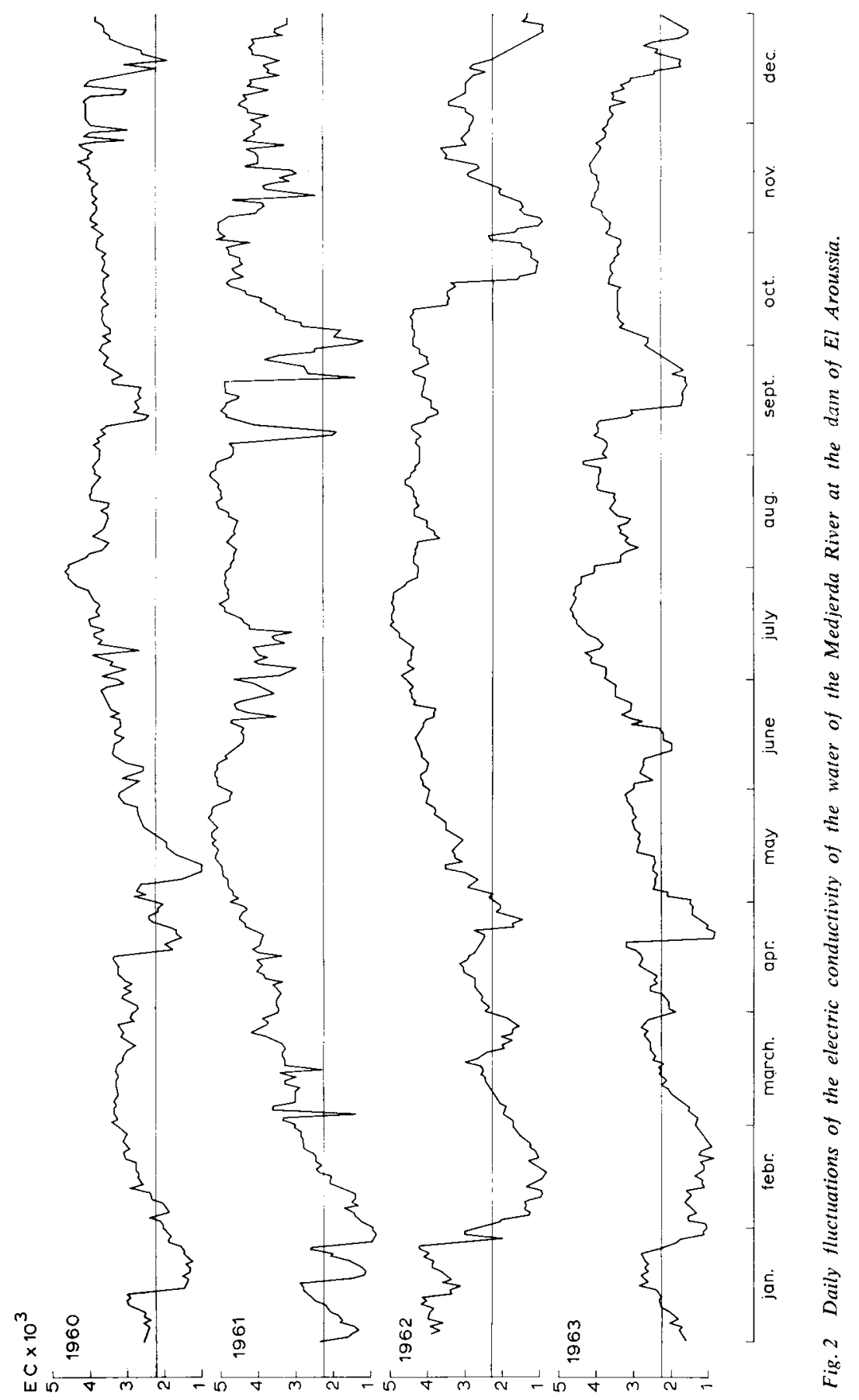


points to a poor quality of the irrigation water, except at a low salt content.

SAR $=\frac{\mathrm{Na}+}{\sqrt{0.5(\mathrm{Ca}+++}}-\frac{}{\left.\mathrm{Mg}^{++}\right)} \quad$ (in meq.)

points to a poor quality of the irrigation water, except at a low salt content. Generally, the river water has a low salt content during and shortly after the rainy period in February, which holds for the whole catchment area of the river. During these rainy periods the rain water leaches salts from the top soil layer, leaving that layer with such poor structure that leaching of the entire profile is hindered.

\section{The experiment field}

\section{General}

The O.M.V.V.M. selected an experiment field where the relationships between crops, irrigation, drainage, salinity and climate could be studied (Hamdaoui et al., 1961). The experiment field is located at Bejaoua, at $17 \mathrm{~km}$ West of Tunis.

The experiment field covers an area of 14 ha (Fig. 3). It is divided into 4 sections (A, B, C and D), each half section drained at a distance of $30 \mathrm{~m}$ (A30) and the other half at $60 \mathrm{~m}$ (A60). On every section a specific crop rotation is practiced, in which summer- and winter fallow and non-irrigated crops play an important role.

The drain distances were chosen to be able to check the reaction of the groundwater table at distances larger and smaller respectively than the distances calculated by the formula of Hooghoudt. According to this formula a distance of $40 \mathrm{~m}$ was calculated, assuming that $\mathrm{k}=0.35 \mathrm{~m} / \mathrm{day}, \mathrm{d}=2.65 \mathrm{~m}\left(\mathrm{r}_{\mathrm{o}}=0.10 \mathrm{~m}\right), \mathrm{m}_{\mathrm{o}}=0.5 \mathrm{~m}$, $\mathrm{s}=0.0025 \mathrm{~m} /$ day and an impervious layer at a depth of $6 \mathrm{~m}$.

The irrigation water was conveyed from the pumping station at Bejaoua by a concrete flume to the end of the field. From the concrete flume the water flowed through the seguias to the basins of $30 \times 27.5 \mathrm{~m}$.

A meteorological station was built, where the evaporation was measured in open pans (among these was a Class $\mathrm{A}$ pan) and the potential evapotranspiration was measured by lysimeters. The meteorological station is equipped with a registrating raingauge, thermograph, hygrograph, psychrometer, and a Campbell-Stokes sunshine duration recorder. From the different meteorological data the evapotranspiration was calculated according to the formulas of Penman and Blaney-Criddle.

\section{Research programme}

The research programme of the experiment field can be summarized as follows:

a) The study of the reaction of the salinity of the soil on crop, irrigation, drainage and climate. Nearly every month soil samples were taken at depths of 0-20, 20-40, $40-80,80-120$ and $120-160 \mathrm{~cm}$ in every drain section. The electric conductivity of the soil extract $\left(\mathrm{EC}_{\mathrm{e}}\right)$ was measured in the laboratory, according to the method described in Agricultural Handbook nr. 60 (Richards, 1954).

b) The determination of the salt balance:

$S_{\mathrm{I}} \pm \triangle S_{\mathrm{P}}-\mathrm{S}_{\mathrm{D}}=0 \quad$ (in $\mathrm{kg} / \mathrm{ha}$ )

where :

$S_{\mathrm{I}}=$ the quantity of salt added to the soil by irrigation,

$S_{\mathrm{D}}=$ the quantity of salt evacuated by the tile drains, and

$\triangle S_{\mathrm{P}}=$ the difference in salt content at the beginning and the end of the period. 

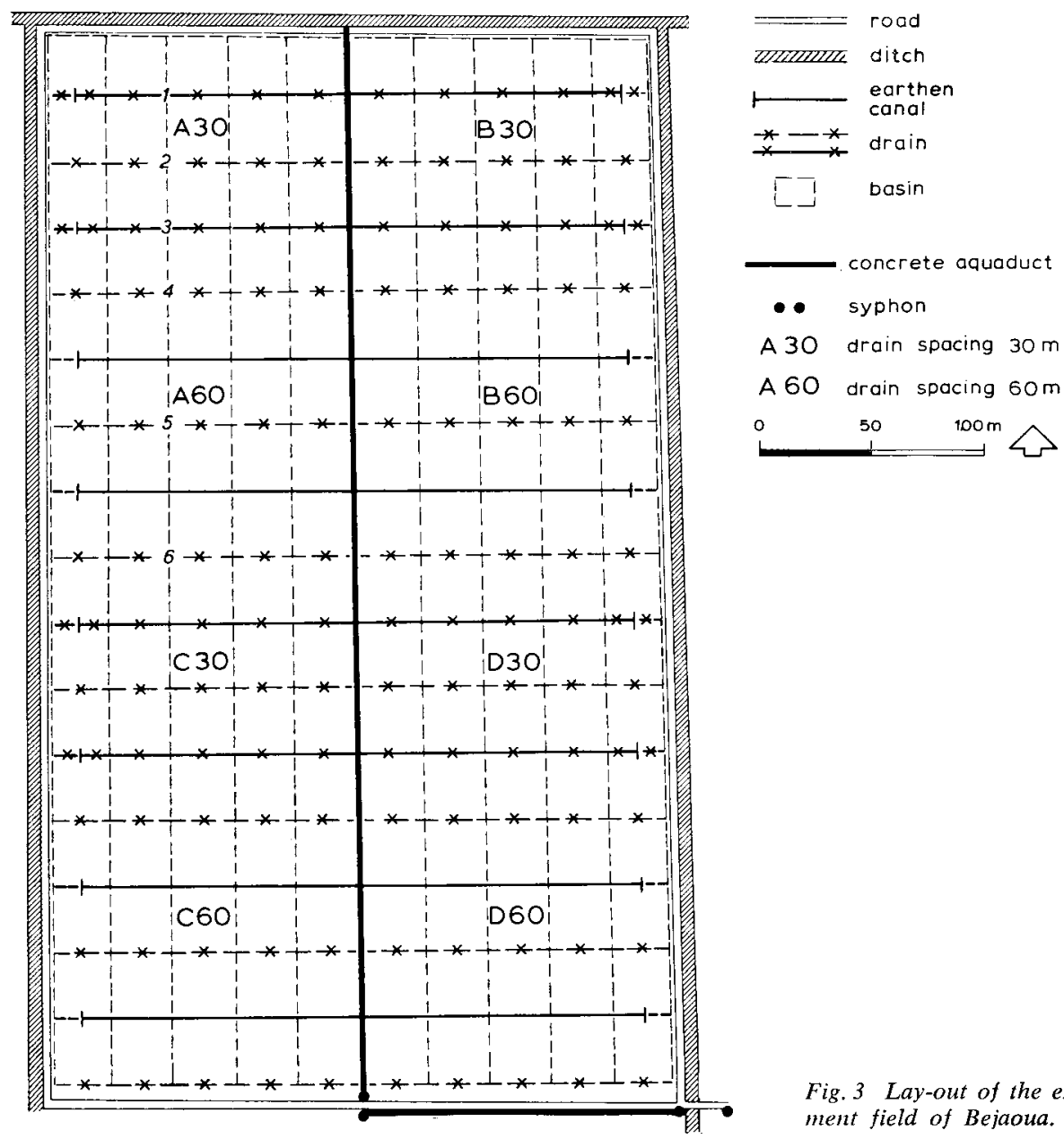

Fig. 3 Lay-out of the experiment field of Bejaoua.

All factors of the salt balance were measured with approximately equal accuracy. An eventual difference in the balance can be attributed amongst other things to the discharge of water to the drainage canals through the subsoil outside the tile drains. The salt content of the irrigation- and drainwater was calculated from EC using the coefficient $\mathrm{K}=0.66$.

The real evapotranspiration (RET) to be calculated from the water balance:

$\mathrm{RET}=\mathrm{P}+\mathrm{I}-\mathrm{D} \pm \triangle \mathrm{C} \quad$ (in surface millimetres per time unit)

where :

$\mathbf{P}=$ precipitation measured at the meteorological station of Bejaoua,

$\mathrm{I}=$ the amount of irrigation water given via the model X-30; the constant supply level is checked a couple of times a day, 
$\mathrm{D}=$ the mean depth of drainage discharge calculated from three measurements a day; for some periods readings were taken every 3 hours,

$\Delta \mathrm{C}=$ the change in storage of moisture in the profile; soil samples were collected monthly from the following depths $0-10$, $20-20,20-30,30-40,40-60,60-80$, $80-100,100-120,120-140$ and $143-163 \mathrm{~cm}$ below the surface.

A drawback of the water balance is, that ali errors accumulate in the evapotranspiration, for example if the quantity of seepage waier is not exactly known.

a) The fluctuations of the water table to be measured in a large number of piezometers, installed in a line perpendicular to the tile drains to a depth of $2.5 \mathrm{~m}$. The water levels were measured once a week, and after an irrigation, or after a rainy period daily.

b) The potential evapotranspiration (PET) to be measured in the lysimeters and calculated according to the equation $P E T=P+1-D$ (in surface millimeters).

The quantity of soil moisture was brought to field capacity as much as possible by nearly daily replacing the evaporated water.

c) To compare the RET and the PET with the open pan evaporation as well as with the $E_{0}$ of Penman as the $E$ of Blaney-Criddle.

The following sections will deal with the salt balance faciors, with soil salinity and with the fluctuations of the water table. Furiner particulars on the water balance will be published elsewhere.

\section{Salinity regime}

\section{irrigation}

The irrigation practice of the experiment field was based on the following principles. i) To avoid high seepage losses of water in the eariaen cinals, and improve uniformity of appilication, a delivery as quick as possible was niade, namely $30 \mathrm{l} / \mathrm{sec}$. In some cases, for example in irrigaîng artichokes and tomatoes, a lower flow was used. Later on it appeared necessary to spread the water over several basins at one time in order to prevent soil erosion.

2) To determine as exact as possible the time of irrigation. For this purpose samples were taken of the upper $20 \mathrm{~cm}$ of the soi with a short auger and the moisiure content was esimated.

3) To stop delivery at the momeni the water arrives at the end of a basin.

The quantity of water consumed per irrigation pariod depended on the available moisture in the soil, the time of the year, and tise development of the crop.

Table 4 gives the minimum and maximum quantities of irrigation water given per irrigation during the two years of the experiment. The minima are in several cases due to a sudden change in weather conditions, in consequence of which the irrigation was stopped. The maximum was approximately $200 \mathrm{~mm}$, very well comparable with the water holding capacity of the soil between $\mathrm{pF} 2.0$ and $\mathrm{pF} 4.2$ (see Table 9). Such maximum applications are often suppiied after a period of rest of the crop (aritichokes in July) or after a fallow period (section A 1963-1964).

During the vegetative period, the intake of water into these heavy clay soils diminishes due to deterioration of the structure. This problem occurs especially with such crops as alfalfa, which remain in the field more than one year. It is in this case necessary to provide a shallow tillage as soon as the soil is sufficiently dry to be walked on. 
Table 4 The quantity of water applied per irrigation ( $\mathrm{mm}$ )

\begin{tabular}{|c|c|c|c|c|c|}
\hline & $\begin{array}{c}\text { Artichoke } \\
1961-1963 \\
\text { section } A, B, D\end{array}$ & $\begin{array}{c}\text { Alfalfa } \\
1961-1963 \\
\text { section C }\end{array}$ & $\begin{array}{c}\text { Tomato } \\
1963 \\
\text { section B }\end{array}$ & $\begin{array}{c}\text { Corn } \\
1963 \\
\text { section D }\end{array}$ & $\begin{array}{c}\text { Broad beans } \\
\text { 1963-1964 } \\
\text { section } A\end{array}$ \\
\hline January & $50-70$ & & & & \\
\hline February & $35-80$ & & & & \\
\hline March & 55 & 110 & & & \\
\hline April & $60-160$ & & & & \\
\hline May & rest period & $120-240$ & & & \\
\hline June & & $100-200$ & 110 & $55-125$ & \\
\hline July & $100-195$ & $130-195$ & $130-190$ & $65-90$ & \\
\hline August & $65-85$ & $95-160$ & $110-135$ & $75-115$ & \\
\hline September & $50-100$ & 90 & & 45 & \\
\hline October & $40-55$ & $90-105$ & & & \\
\hline November & & 105 & & & fallow \\
\hline December & & & & & 200 \\
\hline
\end{tabular}

Table 5 Total depth of irrigation water applied in the growing season ( $\mathrm{mm}$ )

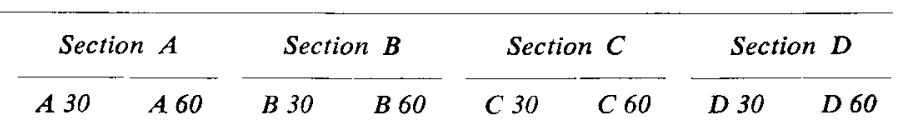

\begin{tabular}{|c|c|c|c|c|c|c|c|c|}
\hline $\begin{array}{l}\text { Alfalfa } \\
1962 \\
1963\end{array}$ & & & & & $\begin{array}{l}1186 \\
1172\end{array}$ & 1235 & & \\
\hline $\begin{array}{l}\text { Artichoke } \\
1961-1962 \\
1962-1963\end{array}$ & $\begin{array}{l}211 \\
530\end{array}$ & $\begin{array}{l}208 \\
493\end{array}$ & 122 & 40 & & & $\begin{array}{l}195 \\
572\end{array}$ & $\begin{array}{l}204 \\
569\end{array}$ \\
\hline $\begin{array}{l}\text { Tomato } \\
1963\end{array}$ & & & (1046) & (1031) & & & & \\
\hline $\begin{array}{l}\text { Corn } \\
1963\end{array}$ & & & & & & & 493 & 482 \\
\hline $\begin{array}{l}\text { Broad beans } \\
1963-1964\end{array}$ & 206 & 199 & & & & & & \\
\hline
\end{tabular}

In Table 5 the total depths of water applied per crop and per growing season are summarized. The alfalfa had been irrigated both years with about $12,000 \mathrm{~m}^{3}$ per ha. The artichokes were given in the first year $2,000 \mathrm{~m}^{3 /} / \mathrm{ha}$, and the second year, when they are fully developed some $5,500 \mathrm{~m}^{3} / \mathrm{ha}$. This difference was chiefly caused by a more favourable distribution of the rainfall in the winter of the first year, but also because of the differences in the vegetation stage. The corn received $5,000 \mathrm{~m}^{3 / \mathrm{ha}}$. The broad beans received a pre-irrigation, as a consequence of lack of rain. The tomatoes were irrigated according to the available data with $10,000 \mathrm{~m}^{3 / h a}$. This is very high, probably there was a loss of water from the irrigation flume directly to the drainage system.

In irrigating, a certain amount of salt is added to the soil, depending on the salt content of the irrigation water and the depth applied. 
SURFACE IRRIGATION WITH SALINE WATER ON A HEAVY CLAY SOIL IN TUNISIA

Table 6 Total quantity of salt $\left(S_{\mathrm{I}}\right.$ in $\left.\mathrm{kg} / \mathrm{ha}\right)$ added to the soil by irrigation

\begin{tabular}{lrrrrrrrr}
\hline & $A 30$ & $A 60$ & $B 30$ & $B 60$ & $C 30$ & $C 60$ & $D 30$ & $D 60$ \\
1962 & 15,905 & 15,669 & 1,534 & 935 & 34,814 & 31,924 & 18,791 & 18,338 \\
1963 & 7,812 & 5,840 & 11,345 & 10,167 & 26,822 & 27,842 & 11,663 & 11,850 \\
Total & 23,717 & 21,509 & 12,879 & 11,102 & 61,636 & 59,766 & 30,454 & 30,188 \\
\hline
\end{tabular}

Table 7 Increase in $E C_{\mathrm{e}}$ (mmho's/cm) under irrigation if there is no leaching

\begin{tabular}{|c|c|c|c|c|c|c|}
\hline \multirow[t]{3}{*}{ Section } & \multicolumn{6}{|c|}{ Depth of soil layer } \\
\hline & \multicolumn{3}{|c|}{$120 \mathrm{~cm}$} & \multicolumn{3}{|c|}{$160 \mathrm{~cm}$} \\
\hline & 1962 & 1963 & total & 1962 & 1963 & total \\
\hline A 30 & 2.65 & 1.30 & 3.95 & 2.00 & 0.95 & 2.95 \\
\hline A 60 & 2.60 & 0.95 & 3.55 & 1.95 & 0.70 & 2.65 \\
\hline B 30 & 0.25 & 1.90 & 2.15 & 0.20 & 1.40 & 1.60 \\
\hline B 60 & 0.15 & 1.75 & 1.90 & 0.12 & 1.30 & 1.42 \\
\hline C 30 & 5.80 & 4.50 & 10.30 & 4.30 & 3.30 & 7.60 \\
\hline C 60 & 5.30 & 4.60 & 9.90 & 3.95 & 3.50 & 7.45 \\
\hline D 30 & 3.10 & 1.95 & 5.05 & 2.30 & 1.45 & 3.75 \\
\hline D 60 & 3.05 & 1.95 & 5.00 & 2.25 & 1.45 & 3.70 \\
\hline
\end{tabular}

Table 6 summarizes these quantities for the years 1962 and 1963 . The total salt amount added by irrigation of the alfalfa rises to more than 60 ton/ha, in contrast to section $\mathrm{B}$, which rises to 12 ton/ha.

There is no doubt that these quantities will influence the salt content of the soil. To make clear that the danger of salinization is high when irrigation is practiced with saline water without an adequate and well-cleaned drainage system, the influence of salt added on the $\mathrm{EC}_{e}$ is given in Table 7 . It is presumed that no salt migrated from the upper layer of the soil into the subsoil. The conversion of the amount of salt into a mean $\mathrm{EC}_{\mathrm{e}}$ per soil layer is done by the formula :

$\mathrm{EC}_{\mathrm{c}}=\frac{\mathrm{S}_{\mathrm{I}}}{64 \times \mathrm{d} \times \mathrm{d}_{\mathrm{b}} \times \mathbf{P}_{\mathrm{w}}}$

where :

$\mathrm{S}_{\mathrm{I}}=\mathrm{kg} / \mathrm{ha}$ of salt added to a certain soil layer on dry weight base (Table 8 ),

$\mathrm{d}=$ depth of soil layer in metres,

$\mathrm{d}_{\mathrm{b}}=$ bulk density $=$ volume weight in $\mathrm{kg} / 1$ (1.43),

$\mathrm{P}_{\mathrm{w}}=$ percentage of water in the soil on dry weight base $(55 \%$ for Bejaoua), and

$\mathrm{EC}_{\mathrm{e}}=$ mean electric conductivity in the entire soil layer $\left(\mathrm{mmho} / \mathrm{s} / \mathrm{cm}\right.$ at $25^{\circ} \mathrm{C}$ ).

It appears that the irrigation of alfalfa leads very quickly to salinization of the soil, whereas irrigation as applied to section $\mathbf{B}$ is considerably less dangerous.

It is interesting to plot the results on the scale given in the Agricultural Handbook nr. 60 (Richards, 1954) and to see what the consequences of the irrigation during the past two years would be if there had been no leaching (Table 8). 
Table 8 Increase in $E C_{\mathrm{e}}$-values due to irrigation during two years without leaching

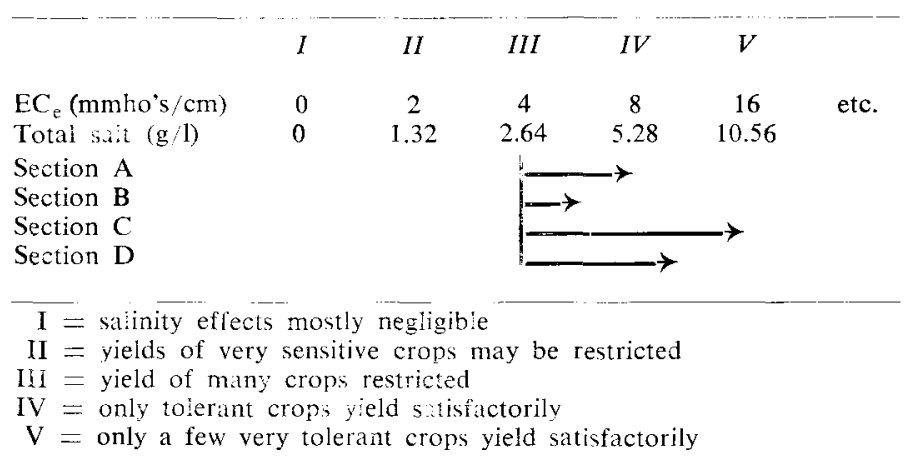

Table 9 Amount of avilable water $(\mathrm{mm})$ between $p F 2.0$ and $p F 4.2$

\begin{tabular}{lrrrrrrrrrr} 
& $0-10$ & $10-20$ & $20-30$ & $30-40$ & $40-60$ & $60-80$ & $80-100$ & $100-120$ & $120-140$ & $140-160$ \\
$\begin{array}{l}\text { Per layer } \\
\begin{array}{l}\text { Total to } \\
\text { bottom of layer }\end{array}\end{array}$ & 14.8 & 17.7 & 15.7 & 14.7 & 30.0 & 31.4 & 30.0 & 22.2 & 28.4 & 29.6 \\
\hline
\end{tabular}

\section{Soil profile}

The soil is the buffer in both the water and the salt balance.

Fig. 4 shows the pF-curve, or moisture characierisiic, of the soil in question. It is the mean pF-curve of 10 soil layers from $0-160 \mathrm{~cm}$ below the surface, since the various curves were in good agreement with eacil other. If the soil dries out to a suction of $\mathrm{pF} 4.2$, which is possible in summerime during fallow or a rest period of the crop, the deficits are as indicated in Table 9.

In the case of $\mathrm{pF} 0.4$ there is $291.6 \mathrm{~mm}$ more than at $\mathrm{pF} 4.2$ and in proportion for shallower layers.

It is now clear that the maximum irrigation applications were of the order of $200 \mathrm{~mm}$, and it is beyond doubt that these amounis do not contribute appreciably to the quantities of water drained off.

If the $\mathrm{EC}_{\mathrm{e}}$, the bulk density $\left(\mathrm{d}_{\mathrm{b}}\right)$ and the percentage water $\left(\mathrm{P}_{\mathrm{w}}\right)$ in the soil are known, the total salt in a soil layer can be calculated from:

$\mathrm{P}_{\mathrm{ss}}=\frac{0.064 \mathrm{EC}_{\mathrm{z}} \mathrm{P}_{w}}{100}$ and $\mathrm{S}_{\mathrm{P}(20)}=2.10^{*} \mathrm{~d}_{\mathrm{b}} \mathrm{F}_{\mathrm{ss}}$

or:

$S_{P(20)}=200(0.064) \cdot E_{c} \cdot P_{w} \cdot d_{b}$

where :

$S_{P_{(20)}}=\mathrm{kg} /$ ha of salt in a $20 \mathrm{~cm}$ soil layer,

$\mathrm{P}_{\mathrm{ss}}=$ per cent salt in soil on dry weight base,

$\mathrm{P}_{\mathrm{w}}=$ percentage water in the soil on dry weight base (55\% for Bejaoua), and

$\mathrm{d}_{\mathrm{b}}=$ bulk density of the soil $=$ volume weight in $\mathrm{kg} / \mathrm{l}$. 
The bulk density for the soil layers $0-20,20-40,40-80,80-120,120-160 \mathrm{~cm}$ below soil surface were $1.33,1.41,1.48,1.46$ and 1.45 , respectively.

In Table 10 the quantities of salt are given to a depth of $160 \mathrm{~cm}$ below surface at 4-11-1963 for the different drain sections.

The total quantity of salt stored in the soil to a depth of $160 \mathrm{~cm}$ below the surface is in general much higher than that added to the soil profile by irrigation (see Table 6).

\section{Drainage}

The experiment field is drained from the middle to both sides. The slope is $20 \mathrm{~cm}$ on $140 \mathrm{~m}$, the tile is at a depih of $140-160 \mathrm{~cm}$ below the soil surface. As mentioned the field is divided into 4 sections ( $A, B, C$ and $D$ ), every section is subdivided into two plots drained with 30 and $60 \mathrm{~m}$ spacing, respectively (Fig. 3).

Table 10 Quantity of total salt $(\mathrm{kg} / \mathrm{ha})$ in the soil layers at 4-11-1963

\begin{tabular}{rrrrrrrrr}
\hline Depth $(\mathrm{cm})$ & $A 30$ & $A 60$ & $B 30$ & $B 60$ & $C 30$ & $C 60$ & $D 30$ & $D 60$ \\
$0-20$ & 3,400 & 3,165 & 5,120 & 4,701 & 3,775 & 4,934 & 4,795 & 3,865 \\
$20-40$ & 3,257 & 3,406 & 4,639 & 4,738 & 5,478 & 7,058 & 4,047 & 3,702 \\
$40-80$ & 7,874 & 8,185 & 8,185 & 8,910 & 15,437 & 18,025 & 8,081 & 8,482 \\
$80-120$ & 8,994 & 9,914 & 8,686 & 9,709 & 17,170 & 18,294 & 11,548 & 11,957 \\
$120-160$ & 11,470 & 18,574 & 15,935 & 17,763 & 18,473 & 18,879 & 18,676 & 18,473 \\
Total & 34,995 & 43,244 & 42,565 & 45,821 & 60,333 & 67,190 & 47,147 & 46,479 \\
\hline
\end{tabular}

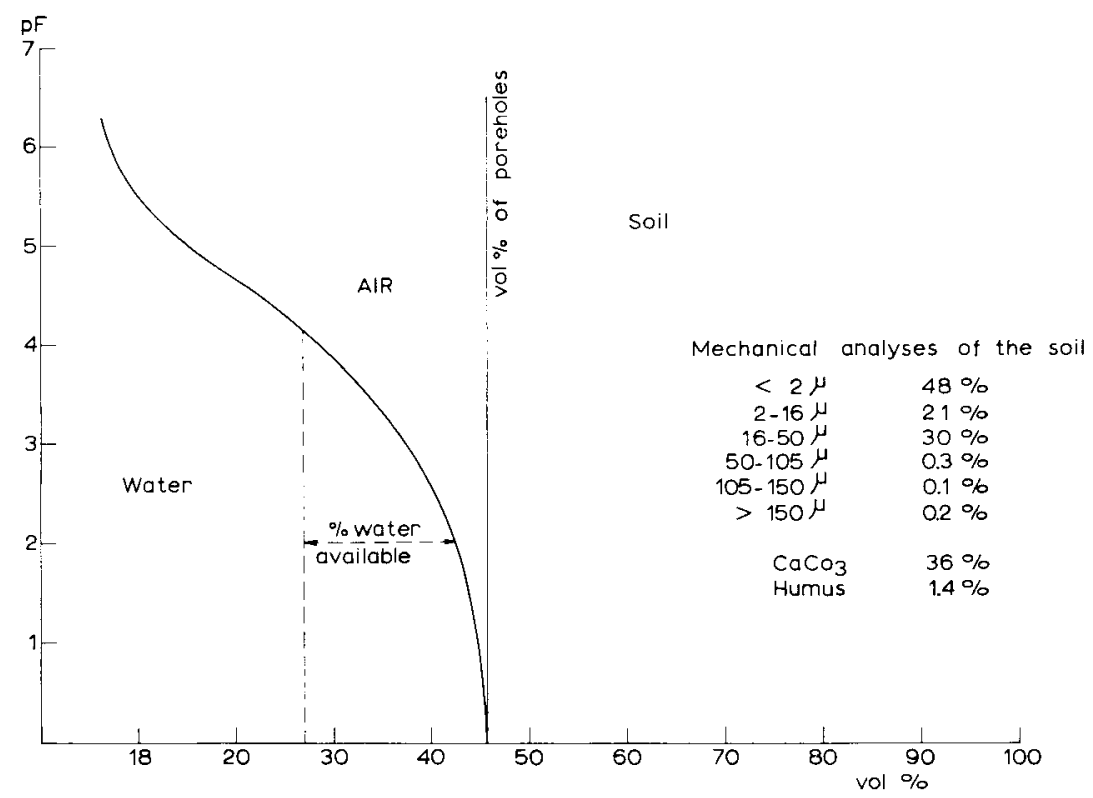

Fig. 4 Moisture retention curve (expressed as $p F=$ negative logarithm of the suction in $\mathrm{cm}$ water) and the mechanical analyses of the soil at Bejaoua. 
During discharge periods, the discharge was generally measured three times a day. Some drains were measured with recorders (Wesseling, 1957), others with a subsurface drain discharge meter (van der Weerd and Visser, 1964) or with a bucket.

In Fig. 5, discharge curves are shown for the drains of section A in August 1962 during and after irrigation, measured every 3 hours during the whole discharge period. From this figure it can be seen that:

- The drains work subsequently from one earthen canal to another.

- The discharge increases very fast, and decreases more slowly immediately after irrigation.

- The maximum discharge of the drains of the $30 \mathrm{~m}$ plots is considerably higher than those of the $60 \mathrm{~m}$ plots.

- The discharge period of the $30 \mathrm{~m}$ drains is much longer than that of the $60 \mathrm{~m}$ drains.

- There is only a short period of maximum discharge.

It can be seen that the total amount of water discharged from the $30 \mathrm{~m}$ plots is much higher than that of the $60 \mathrm{~m}$ plots. This result was not expected. It is probable that in particular on the $60 \mathrm{~m}$ plots the irrigation water in part flows directly through the subsoil into the open drainage system.

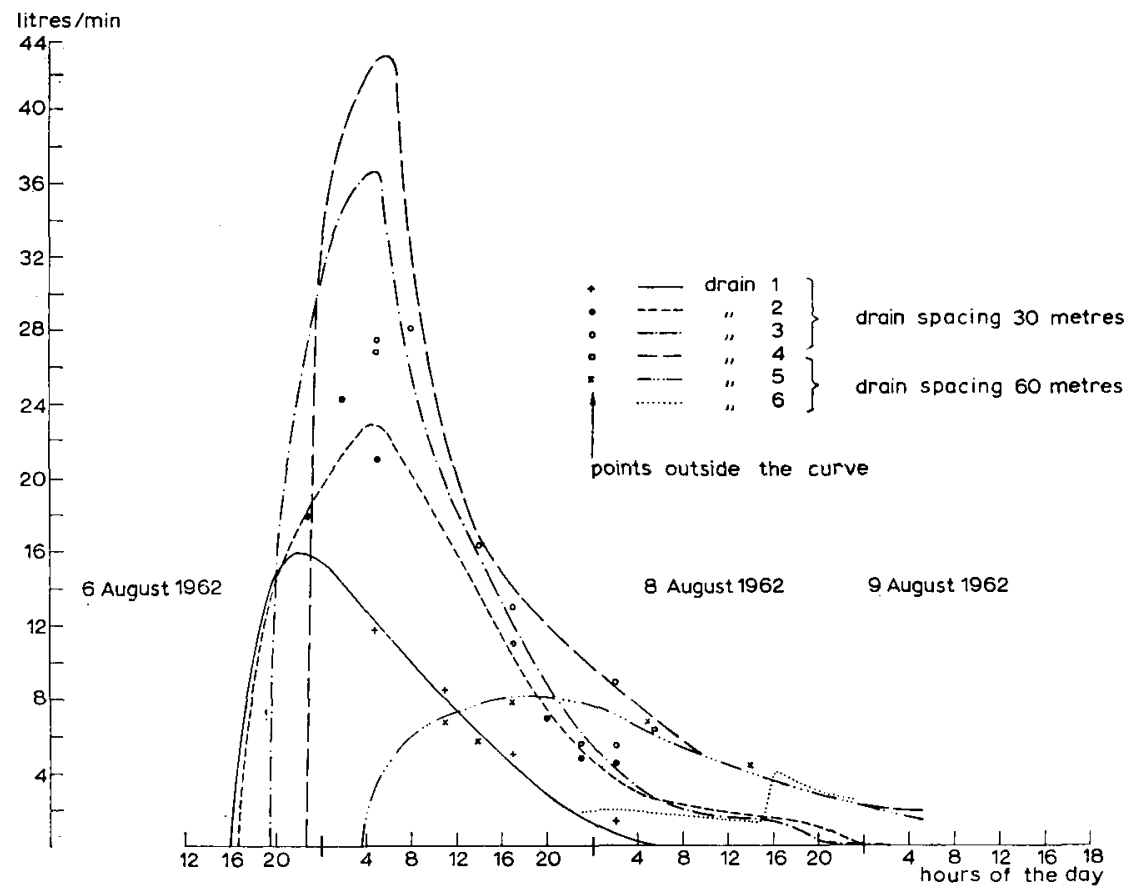

Fig. 5 Discharge curves of the drains in section $A$ during and after irrigation. The curves have been strictly drawn through almost all available points. In the figure these points have, for clarity sake, not been drawn in, only those points not falling on the relevant curves are given. 
In Table 11 examples are shown of the total drain discharge per month during the years 1962 and 1963, of the total quantities and of the discharge during the winter 1962-1963 in mm depth of water. The drain discharges are in general small. The total discharge of the $30 \mathrm{~m}$ drained plots is more than the discharge of the $60 \mathrm{~m}$ plots. It can be concluded once more that possibly in the $60 \mathrm{~m}$ plots a relatively larger discharge takes place through the subsoil tot the open drainage system, or that the evapotranspiration on the $60 \mathrm{~m}$ plots was higher.

The discharge in section $C$ in 1962 during May and June was chiefly due to the irrigations of 250 and $280 \mathrm{~mm}$ per month, respectively. In February 1963 there was $81.6 \mathrm{~mm}$ precipitation.

Simultaneously with measuring the drain discharge, a water sample of the drainage water was taken of which the EC was determined in the laboratory. The result multiplied by 0.66 gives the weight of the total salts in grams per litre.

In Table 12 an example is given of the electrical conductivity of the drain water in section A from 17-21 July, 1962. The differences between the EC's of one drain in the course of the period are small. The EC's of the various drains lie in the same range of values. The same holds for other sections and other periods.

In comparing the results of the whole year it appears that there are also only small differences, probably due to the buffering subsoil salinity.

In the period of 17-21 July a salt content of about $4.5 \mathrm{~g} / 1$ is found, whereas the irrigation water contained $3 \mathrm{~g} / \mathrm{l}$. From the small fluctuation in the salt content of the drain water it can be concluded that the efficiency of leaching of the soil by rain water is much higher than that by the irrigation water, since the fluctuation over the year of the salt content in the drain water is only very small.

The total quantity of salt evacuated by drainage is shown in Table 13 . These quantities are very low when compared with the quantities added by the irrigation (up to $60,000 \mathrm{~kg}$ in 2 years).

Table 11 Drain discharges during 1962 and 1963 ( $\mathrm{mm}$ depth)

\begin{tabular}{|c|c|c|c|c|c|c|c|c|}
\hline & \multicolumn{2}{|c|}{1962 artichokes } & \multicolumn{2}{|c|}{1962 artichokes } & \multicolumn{2}{|c|}{1962 alfalfa } & \multicolumn{2}{|c|}{1963 alfalfa } \\
\hline & A 30 & A 60 & B 30 & $B 60$ & C 30 & $C 60$ & C 30 & $C 60$ \\
\hline April & 19.7 & 13.9 & 5.8 & 3.0 & 0 & 0 & 15.7 & 0.9 \\
\hline March & 13.0 & 11.7 & - & 17.0 & 10.7 & 2.7 & 31.8 & 18.3 \\
\hline May & 0 & 0 & 0 & 0 & 0 & 0 & 17.0 & 11.7 \\
\hline January & 0 & 0 & 0 & 0 & 0 & 0 & 0 & 0 \\
\hline February & 0 & 0 & 0 & 0 & 20.0 & 17.6 & 1.5 & 3.3 \\
\hline June & 0 & 0 & 0 & 0 & 22.9 & 37.4 & 4.1 & 4.9 \\
\hline July & 3.1 & 0.7 & 0 & 0 & 1.4 & 2.9 & 6.2 & 4.5 \\
\hline August & 15.6 & 2.5 & 0 & 0 & 5.2 & 7.0 & 7.4 & (7.9) \\
\hline September & 3.3 & 0.2 & 0 & 0 & 2.4 & 4.2 & 0 & 0 \\
\hline \multicolumn{9}{|c|}{ bersim } \\
\hline October & (10.9) & $(5.0)$ & (3) & (3) & $(17.9)$ & (17.9) & 6.2 & 4.2 \\
\hline November & 11.0 & 7.7 & - & 5.0 & 10.5 & 6.4 & 0.8 & 15.6 \\
\hline December & 0.1 & 0 & 0 & 0 & 0 & 0 & 1.6 & 1.7 \\
\hline Total & 76.7 & 41.7 & $(8.8)$ & 28.0 & 91.0 & 96.1 & 92.1 & 73.0 \\
\hline $\begin{array}{l}\text { Sept.-March } \\
\text { incl. 1962-1963 }\end{array}$ & 129.0 & 54.6 & 55.0 & 36.0 & 93.3 & 59.4 & & \\
\hline
\end{tabular}




\section{Salt balance}

The salt balance can, as mentioned under Research programme, be written as follows:

$\mathbf{S}_{\mathrm{I}}+\triangle \mathbf{S}_{\mathrm{P}}-\mathbf{S}_{\mathrm{D}}=0 \quad$ (in $\mathrm{kg} / \mathrm{ha}$ )

In Table 14 an example is given of the balance for a long period of time, 30-11-1961 up to 4-11-1963. In five plots the quantity of stored salt decreased when compared with the amounts on 4-11-1963. In the sections C 30 and $C$, 0 , the most heavily irrigated parts of the experiment field, the quantity of stored salt increased considerably. It appears from the last column that more salt disappeared out of each plot than was evacuated by the tile drainage system.

There are two possibilities: a) the salt was stored below sampling depth in the subsoil; b) the salt was evacuated by a subsoil flow of water directly into the open drain system.

Table 12 Electrical conductivity of the drain water from the drains in section $A$, in July 1962

\begin{tabular}{|c|c|c|c|c|c|c|c|}
\hline \multirow[t]{2}{*}{ Date } & \multirow[t]{2}{*}{ Hour } & \multicolumn{6}{|c|}{ Drain } \\
\hline & & 1 & 2 & 3 & 4 & 5 & 6 \\
\hline \multirow[t]{3}{*}{$17-7$} & 16.00 & 6.90 & & & & & \\
\hline & 20.00 & 6.50 & & & & & \\
\hline & 23.00 & 6.80 & 7.00 & & & & \\
\hline \multirow[t]{10}{*}{$18-7$} & 02.00 & 6.80 & 6.80 & & & & \\
\hline & 05.00 & 7.00 & & & & & \\
\hline & 08.30 & 7.00 & 6.05 & 7.05 & & & \\
\hline & 10.30 & 7.00 & 6.40 & & & & \\
\hline & 12.30 & 6.40 & 6.50 & 7.00 & & & \\
\hline & 14.30 & 6.50 & 6.55 & & & & \\
\hline & 16.30 & 6.50 & 6.40 & 6.20 & & & \\
\hline & 18.30 & & 6.90 & 6.00 & & & \\
\hline & 20.00 & & 6.90 & 6.60 & & & \\
\hline & 23.00 & & 6.70 & 6.35 & 6.70 & & \\
\hline \multirow[t]{8}{*}{$19-7$} & 02.00 & & 7.10 & 6.30 & 7.10 & & \\
\hline & 05.00 & & 6.80 & 6.35 & 7.00 & & \\
\hline & 8.30 & & 7.10 & 6.60 & 7.10 & & \\
\hline & 10.30 & & 7.10 & 6.70 & 7.00 & & \\
\hline & 12.30 & & & 660 & 7.00 & & \\
\hline & 16.30 & & & 6.49 & 7.10 & & \\
\hline & 20.00 & & & 6.30 & & & \\
\hline & 23.00 & & & 6.20 & 7.00 & 7.25 & \\
\hline \multirow[t]{9}{*}{$20-7$} & 02.00 & & & 6.50 & 6.35 & & \\
\hline & 05.00 & & & 6.05 & 6.80 & 7.20 & \\
\hline & 08.30 & & & 6.60 & 6.70 & 7.25 & \\
\hline & 10.30 & & & 6.10 & 6.40 & 7.20 & \\
\hline & 12.39 & & & 6.50 & 6.70 & 7.30 & \\
\hline & 14.30 & & & 6.50 & & & \\
\hline & 16.30 & & & & 6.90 & 7.00 & \\
\hline & 20.00 & & & & 7.00 & 7.10 & \\
\hline & 23.00 & & & & 7.10 & 7.10 & \\
\hline \multirow[t]{5}{*}{$21-7$} & 02.00 & & & & 7.10 & 6.90 & \\
\hline & 05.00 & & & & 6.90 & 7.00 & 6.50 \\
\hline & 08.00 & & & & & 7.00 & \\
\hline & 14.00 & & & & & & \\
\hline & 16.00 & & & & 7.10 & & \\
\hline
\end{tabular}


Table 13 Total quantity of salt $(\mathrm{kg} / \mathrm{ha})$ evacuated by drain water

\begin{tabular}{|c|c|c|c|c|c|c|c|c|}
\hline & A 30 & A 60 & $B 30$ & $B 60$ & C 30 & C 60 & $D 30$ & $D 60$ \\
\hline 1962 & 2,963 & 1,839 & 696 & 783 & 4,208 & 4,362 & 2,910 & 2,022 \\
\hline 1963 & 3,726 & 3,194 & 2,349 & 2,154 & 4,704 & 2,964 & 3,313 & 1,276 \\
\hline Total & 6.689 & 5,033 & 3,045 & 2,937 & 8,912 & 7,326 & 6,223 & 3,298 \\
\hline
\end{tabular}

Table 14 Salt balance from 30-11-1961 to 4-11-1963

\begin{tabular}{|c|c|c|c|c|c|c|c|}
\hline \multirow[t]{4}{*}{ Section } & \multicolumn{6}{|c|}{ Quantities of salt (in $\mathrm{kg}$ ) } & \\
\hline & \multirow{2}{*}{$\begin{array}{c}\text { irrigation } \\
\text { water } \\
S_{1}\end{array}$} & \multirow[b]{2}{*}{$30-11-6 I$} & \multicolumn{2}{|c|}{ profile } & \multirow[b]{2}{*}{ total } & \multicolumn{2}{|c|}{ drainage } \\
\hline & & & $4-11-63$ & $\begin{array}{c}\text { change } \\
\triangle S_{P}\end{array}$ & & $\begin{array}{c}\text { drain } \\
S_{\mathrm{D}}\end{array}$ & $\begin{array}{c}\text { subsoil } \\
S_{\mathrm{D}}^{\prime}\end{array}$ \\
\hline & 1 & & & 2 & $1-2$ & 3 & $1-2-3$ \\
\hline A 30 & 18,601 & 38,735 & 34,995 & $-3,740$ & 22,341 & 8,169 & 14,172 \\
\hline A 60 & 17,184 & 41,926 & 43,244 & $+\quad 1,318$ & 15,866 & 4,174 & 11,692 \\
\hline B 30 & 12,879 & 49,727 & 42,565 & $-7,162$ & 20,041 & 3,045 & 16,996 \\
\hline B 60 & 11,102 & 47,608 & 54,821 & $-1,787$ & 12,889 & 2,937 & 9,952 \\
\hline C 30 & 58,969 & 45,857 & 60,333 & $-14,476$ & 44,493 & 8,800 & 35,693 \\
\hline C 60 & 57,115 & 52,446 & 67,190 & $+14,744$ & 42,371 & 7,224 & 35,147 \\
\hline D 30 & 30,454 & 54,089 & 47,147 & $-6,942$ & 37,396 & 6,223 & 31,173 \\
\hline D 60 & 30,188 & 60,387 & 46,479 & $-13,908$ & 44,096 & 3,298 & 40,800 \\
\hline
\end{tabular}

Concerning the subsoil storage no data are available, but certainly a part of the total evacuated quantity of salt will have been stored there, as Table 10 and 11 indicate. Even below $160 \mathrm{~cm}$ there are still fluctuations in salt content in the deeper layers. There are some indications, that groundwater is flowing directly to the open drainage system outside the sphere of influence of the drains. These indications are:

- Iron sedimentations at the bottom and sides of the drainage canals.

- Glistening sides of the canals, indicating seepage of groundwater through the pores.

- The quantity of water drained by the $30 \mathrm{~m}$ plots is considerable higher than that of the $60 \mathrm{~m}$ ones.

- The total quantity of drainage water is surprisingly low in summer as well as in winter.

It is possible to get an indication of the amount of saline water that is draining to the deeper subsoil or directly to the open drainage system. If the $\mathrm{EC}_{\mathrm{e}}$ of the water in question was known, the amount of water could be calculated with the aid of the last column of Table 14.

When taking a certain $\mathrm{EC}_{\mathrm{e}}$, extrapolated from the values as found in the higher subsoil (see Table 10 and 11), the following formula will give the equivalent amount (as a depth) of water evacuated outside of the drainage system:

$$
\mathrm{A}=\frac{\mathrm{S}_{\mathrm{D}}^{\prime}}{10 . \mathrm{K} \cdot \mathrm{EC}_{\mathrm{e}}}
$$

where: $A=$ amount of water expressed as a depth in $\mathrm{mm}$,

$\mathbf{S}_{\mathrm{D}}^{\prime}=$ salt balance deficit (the salt lost to subsoil or directly to open system), and

$\mathrm{K}=$ transformation coefficient of $\mathrm{EC}_{\mathrm{e}}$ into $\mathrm{g} /$ litre (here taken at 0.66 ). 
In Table 15 the equivalent amounts are given in the cases that the $\mathrm{EC}_{e}$ of the deeper subsoil is the extrapolated value from Table 11 at a depth of $2 \mathrm{~m}$, and the higher values of 15 and $30 \mathrm{mmho's} / \mathrm{cm}$.

If this number of millimetres (A) is divided by the number of effective days, that is to say the number of days of irrigation- and rainy periods, an estimation of the number of millimetres of flow per day to the open drainage system will be found. The results of this procedure are not entirely in agreement with the differences found in the drain discharges for the 30 and $60 \mathrm{~m}$ sections, respectively. This is due to the difficulty in getting a reliable mean of the salt content of the soil profile.

Table 15 Calculation of the equivalent water depth $(A)$ of the salt balance deficit $\left(S^{\prime} \mathrm{D}\right)$ for different $E C_{\mathrm{e}}$ 's of the subsoil

\begin{tabular}{|c|c|c|c|c|c|c|c|c|c|}
\hline \multirow[t]{3}{*}{ Section } & \multirow[t]{3}{*}{$S^{\prime} \mathrm{D}$} & \multirow{3}{*}{$\begin{array}{c}\text { Subsoil } \\
E C_{\mathrm{e}}\left(\times 10^{\mathrm{z}}\right)\end{array}$} & \multicolumn{6}{|c|}{$\boldsymbol{A}$} & \multirow{3}{*}{$\begin{array}{c}\text { Number } \\
\text { of } \\
\text { effective } \\
\text { days }\end{array}$} \\
\hline & & & \multicolumn{3}{|c|}{ per period for $E C_{\mathrm{e}}$} & \multicolumn{3}{|c|}{ per day for $E C_{e}$} & \\
\hline & & & $\begin{array}{c}\text { variable } \\
\text { acc. } \\
\text { column } 3\end{array}$ & 15 & 30 & $\begin{array}{c}\text { variable } \\
\text { acc. } \\
\text { column } 3\end{array}$ & 15 & 30 & \\
\hline A 30 & 14,172 & 9 & 240 & 143 & 72 & 0.57 & 0.34 & 0.17 & 420 \\
\hline A 60 & 11,692 & 10 & 177 & 118 & 59 & 0.42 & 0.28 & 0.14 & 420 \\
\hline В 30 & 16,996 & 12 & 215 & 171 & 86 & 0.48 & 0.38 & 0.19 & 450 \\
\hline В 60 & 9,952 & 12 & 126 & 100 & 50 & 0.28 & 0.22 & 0.11 & 450 \\
\hline C 30 & 35,693 & 12 & 452 & 360 & 180 & 0.64 & 0.51 & 0.26 & 700 \\
\hline C 60 & 35,147 & 12.5 & 429 & 355 & 178 & 0.61 & 0.50 & 0.25 & 700 \\
\hline D 30 & 31,173 & 12.5 & 380 & 314 & 157 & 0.63 & 0.52 & 0.26 & 600 \\
\hline D 60 & 40,800 & 13 & 474 & 408 & 204 & 0.79 & 0.68 & 0.34 & 600 \\
\hline
\end{tabular}

\section{Influence of crop rotation on soil salinity}

At a certain salinity level in the soil the yields of crops decrease depending on the tolerance of the crop concerned. On account of the salinity of the irrigation water it was obvious that not every crop could be grown in the Medjerda Valley. It was necessary therefore to choose crops which can be expected to prosper under these circumstances. Amongst these there are some crops familiar to the Tunisian farmer and some new crops that could be introduced. Important vegetable crops are artichokes, melons and watermelons. According to the general experience in North Africa these crops can be compared with tomatoes and cucumbers, respectively, from the viewpoint of salinity resistance.

Among the forage crops alfalfa is the most promising crop for the Medjerda Valley. The most interesting field crops are barley and wheat.

The electrical conductivity of the soil was determined from the extract of saturated soil samples. The mean saturation percentage at Bajaoua was $55 \%$.

The crop rotation depends on the soil salinity, at the beginning of the sowing period as well as the development of the $\mathrm{EC}_{\mathrm{c}}$ during the growing season.

In Fig. 6 two examples are given of the fluctuations in the $\mathrm{EC}_{\mathrm{e}}$-values of the different soil layers from 1961 through 1963. It should be emphasized that the results were obtained without artificial leaching by irrigation water. 
In Table 16 the crop rotation on the experiment field of Bejaoua, the irrigation intensity and the general conclusion on salinity trends are given.

Table 16 Crop rotation for the sections of the experiment field

\begin{tabular}{|c|c|c|c|c|}
\hline & Section $A$ & Section B & Section $C$ & Section $D$ \\
\hline End 1961 & artichokes & artichokes & alfalfa & artichokes \\
\hline Winter $1961-1962$ & artichokes & artichokes & alfalfa & artichokes \\
\hline Summer 1962 & artichokes & fallow & alfalfa & artichokes \\
\hline Winter $1962-1963$ & artichokes & bersim & alfalfa & artichokes \\
\hline Summer 1963 & fallow & tomatoes & alfalfa & corn \\
\hline Winter $1963-1964$ & beans & barley & alfalfa & fallow \\
\hline Irrigation : & $\begin{array}{l}\text { fairly } \\
\text { intensive }\end{array}$ & extensive & intensive & $\begin{array}{l}\text { fairly } \\
\text { intensive }\end{array}$ \\
\hline Salinity: & stable & $\begin{array}{l}\text { slight } \\
\text { improvement }\end{array}$ & $\begin{array}{l}\text { slight } \\
\text { deterioration }\end{array}$ & stable \\
\hline
\end{tabular}
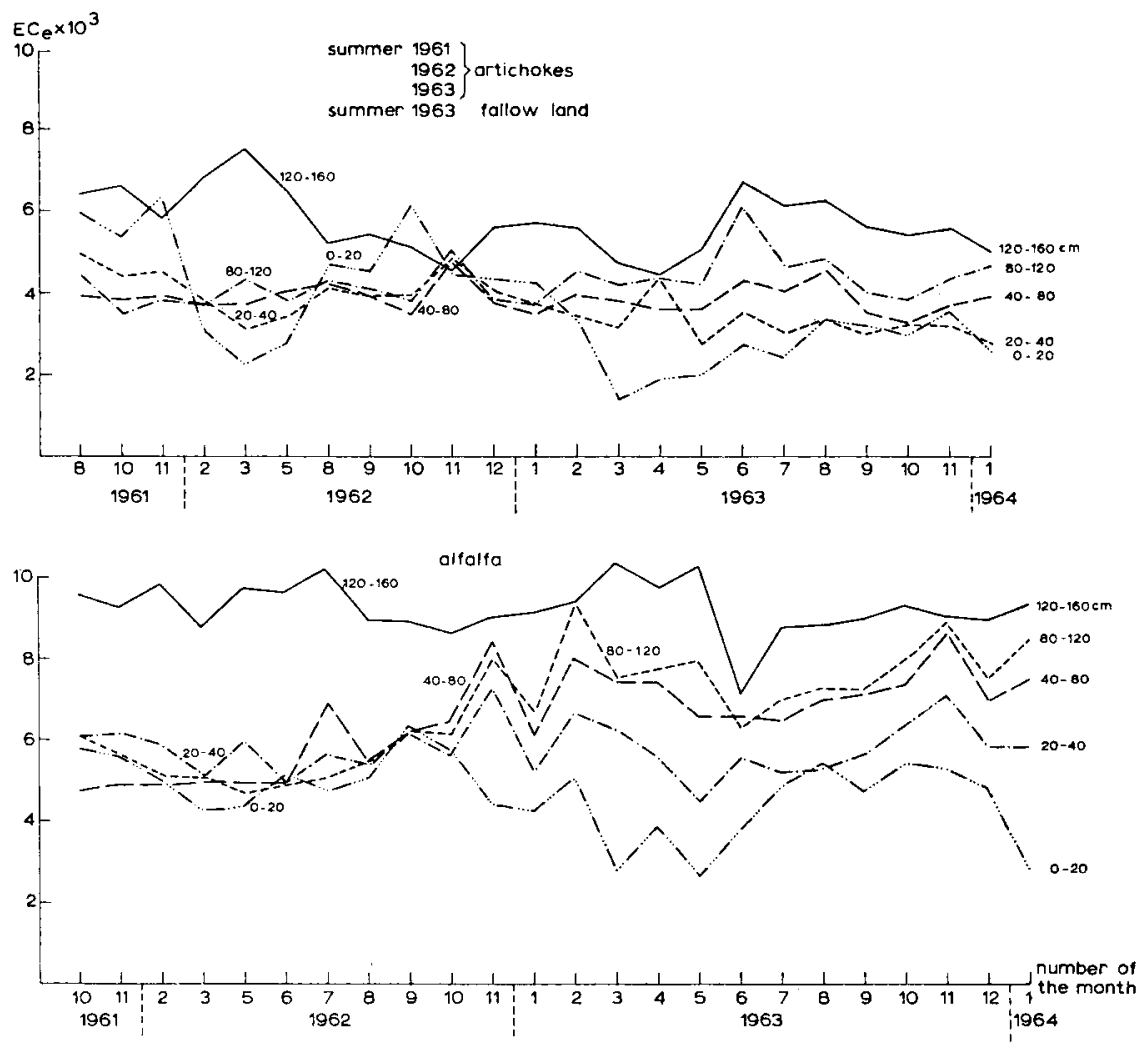

Fig. 6 Fluctuation in salinity of the various soil layers of sections A30 (top) and C 60 (bottom) during the period of investigation at Bejaoua. 


\section{Conclusions and recommendations}

From the information given above and from other available information on the given subject, the following conclusions and recommendations can be given.

1) There is no big difference in the salt content of the soil of the two different plots of one section, drained at 30 and $60 \mathrm{~m}$, respectively. In Fig. 7 the mean of ail samples taken in the period of August 1961 through December 1963 is given.

2) The subsoil of the sections $A$ and $B$ is less saline than that of $C$ and D, probably due to the influence of the open drainage system on three sides (Fig. 1).

3) After 2 years of growing artichokes in section A, no harmful effect was observed from irrigation with brackish water. The dying of a number of cuttings was due to the method of planting. The wet soil caked hard over the plant upon drying, preventing emergence. In total this section was irrigated with some $700 \mathrm{~mm}$ of water. In the upper $120 \mathrm{~cm}$ of the soil profile the $\mathrm{EC}_{\mathrm{c}}$ was seldom higher than 5 . For artichokes it was as regards soil salinity an acceptable environment.

4) In section B there was only a slight difference in salinity between the different layers of the two plots. The crop rotation was irrigation extensive. Only during the summer of 1964 this section grown with tomatoes was irrigated abundantly. Especially in 1962 and in spring 1963 an improvement in soil salinity was found. In this section the $\mathrm{EC}_{\mathrm{e}}$ fluctuated between 4 and 6 , which means that many crops could be grown.

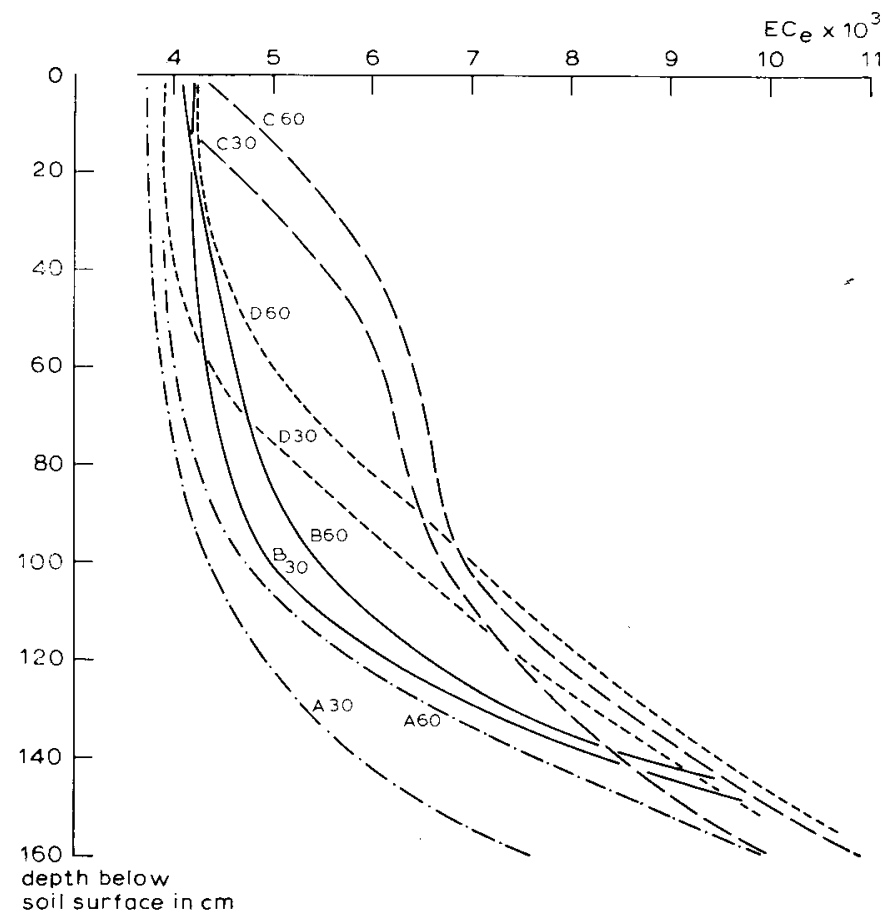

Fig. 7 Mean soil salinity for the sections of the field at Bejaoua at various depths of the soil profile. 
5) In section $\mathrm{C}$ alfalfa was grown from the beginning to the end of the report period. Every year the soil was irrigated with $1000-1200 \mathrm{~mm}$ water. These quantities had an important influence. Especially the layers at $40-80$ and $80-120 \mathrm{~cm}$ depth showed an increase in salinity. After the alfalfa the soil needs a fallow period and in connection with leaching of the soil, the winter period is to be preferred. In 1963 the $\mathrm{EC}_{\mathrm{c}}$ generally did not exceed values of 8 or 9 which can be tolerated. But the growing conditions were less favourable than in sections $\mathrm{A}$ and $\mathrm{B}$.

6) Compared with the sections $\mathrm{A}$ and $\mathrm{B}$, section $\mathrm{D}$ was irrigated fairly intensively. Immediately after the artichokes, corn was planted. Nevertheless the salt situation was favourable if compared with that in section $\mathrm{C}$. The $\mathrm{EC}_{\mathrm{e}}$ of the layer at 80 $120 \mathrm{~cm}$ fluctuated between 7 and 8 , whereas the electric conductivity in the other layers was much less. The development of corn was a bit retarded. Also in this section there was a tendency towards improvement of the situation.

7) It is recommended that a crop rotation is taken in which, besides fallow periods, wintercrops and perennials with a rest period in summer, like artichokes, have their place.

\section{Groundwater fluctuations through irrigation and drainage}

The fluctuations of the groundwater level were studied in a number of observation wells placed along the length of the experiment field, in the middle of the sections in lines perpendicular on the tile lines. The wells were made from galvanized iron tubes with a length of $3 \mathrm{~m}$ and a diameter of $5 \mathrm{~cm}$. The tubes were perforated over a length of $250 \mathrm{~cm}$. The upper $50 \mathrm{~cm}$ was not perforated in order to prevent surface run-off from flowing into the tubes.

In general the water table was measured every Monday. After irrigation and heavy rainfall, daily observations were carried out.

The observations are evaluated per plot. In general it can be concluded that the groundwater level was found at drainage depth, except shortly after heavy rain and irrigation gifts; in dry periods the groundwater level was below drain level.

During irrigation the groundwater level rises to the soil surface, filling up the fissures. Soon after irrigation the water is absorbed by the swelling soil. The problem arises, how much time is needed before the groundwater level reaches a level at which it does not hamper plant growth by asphyxiation of the roots.

From the different series of data it can be concluded that the periods of temporary groundwater rise due to irrigation are shorter in the sections of $30 \mathrm{~m}$ spacing than in those of $60 \mathrm{~m}$.

In Fig. 8 an example is given of the reactions of the groundwater level in tube 57 of the $60 \mathrm{~m}$ drained plot of section C (alfalfa), the most intensively irrigated part of the experiment field. In general the groundwater level reached a level lower than $0.50 \mathrm{~m}$ below soil surface within one day after irrigation and after 3 or 4 days the phreatic surface sank to a level of $1 \mathrm{~m}$ or more below soil surface.

The drain spacing of $60 \mathrm{~m}$ was sufficient for drainage, due to the water absorption capacity of the clay soil and the high evapoiranspiration in dryer periods. 

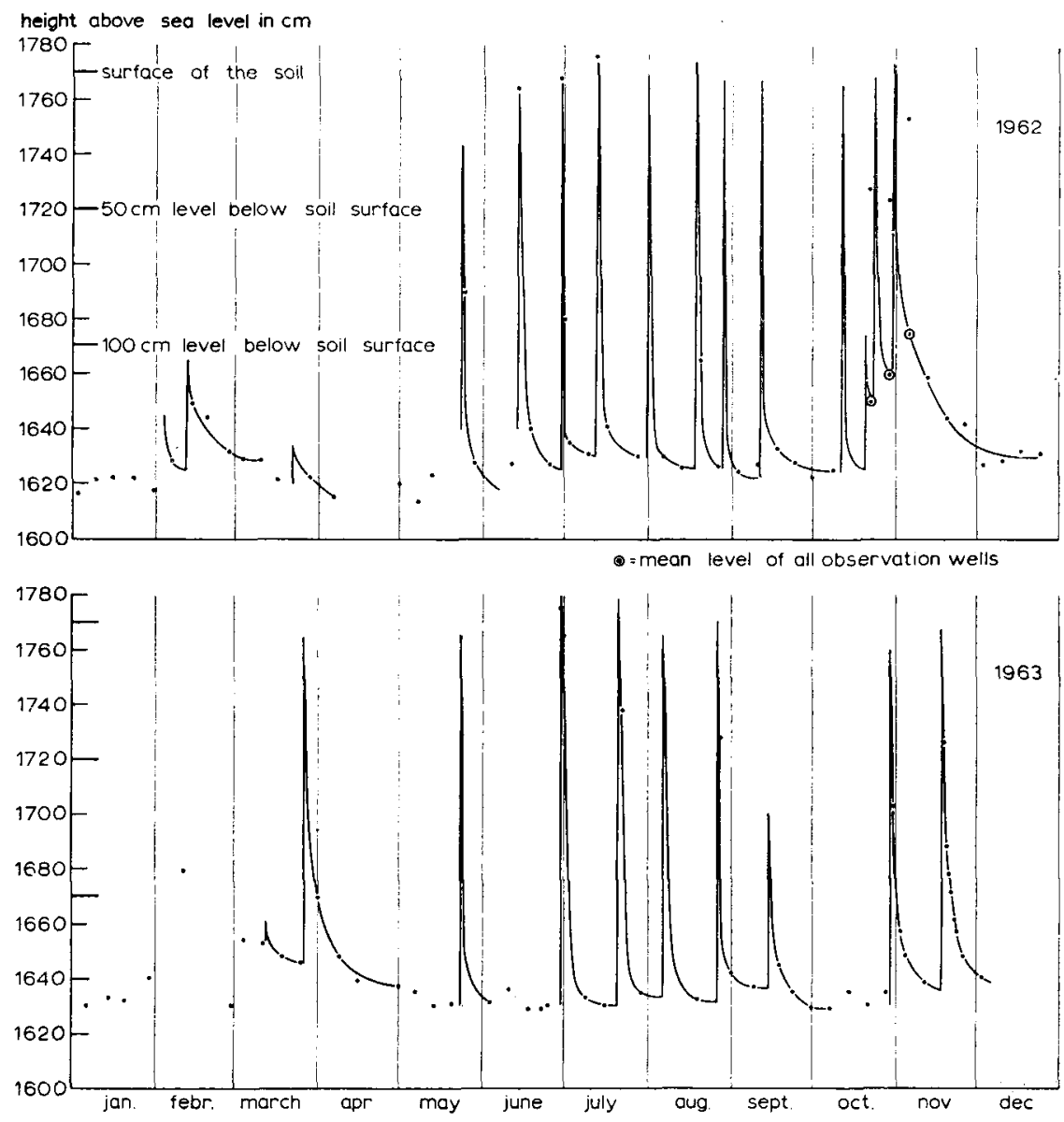

Fig. 8 Fluctuations of the groundwater level in observation well 57 at Bejaoua $(60 \mathrm{~m}$ plot of section $C$ ).

\section{Acknowledgements}

The authors are grateful to the Office de la Mise en Valeur de la Basse Vallée de la Medjerda for consenting to have some of the results of their investigation published. They are also greatly indebted to Professor Dr. C. van den Berg, Director of the Institute for his advice and comments given during the investigation.

\section{References}

Beers, W. F. J. van, 1958. The auger hole method. Intern. Inst. Land Reclamation Improvement. Wageningen, Bull., 1.

Hamdaoui, S., Hernot, A. et Hoorn, J. W. van, 1961. Fonctionnement de la parcelle d'expérimentation de Bejaoua. Rapport de l'Office de la Mise en Valeur de la Vallée de la Medjerda (Service Pédologique). 
Hooghoudt, S. B., 1934. Bijdragen tot de kennis van enige natuurkundige grootheden van de grond. II. Versl. Landbouwk. Onderz, 40.B.

Hoorn, J. W. van, 1961. Les valeurs climatologiques de la station Tunis-Manoubia. Rapport de l'Office de la Mise en Valeur de la Vallée de la Medjerda (Service Pédologique).

Hoorn, J. W. van, 1963. In: Ann. Rept. 1962 Inst. Land Water Management Res., Wageningen, pp. $42-45$.

Leven, J. A. van 't, 1964. In: Ann. Rept. 1963 Inst. Land Water Management Res., Wageningen, pp. 71-77.

Richards, L. A. (Editor), 1954. Diagnosis and improvement of saline and alkali soils. Agricultural Handbook No. 60, U.S. Dept. Agr., Washington, D.C.

Talsma, T., 1963. The control of saline groundwater. Mededel. Landbouwhogeschool Wageningen, 63-10, $68 \mathrm{pp}$.

Weerd, B. van der en Visser, W. C., 1964. Een apparaat voor het meten van draindebieten onder water en enkele op deze meting steunende resultaten. Cultuurtech. Tijdschr., 4 (4); Misc. Repr. 34, Inst. Land and Water Management Res., Wageningen.

Wesseling, J., 1957. Enige aspecten van de waterbeheersing in landbouwgronden. Versl. Landbouwk. Onderz., 63.5 .

Westerhof, J. J., 1962. Land development project in Tunisia. The Way Ahead, 9 (1). 